\title{
Identification of 13 novel mutations including a retrotransposal insertion in SLC25A13 gene and frequency of 30 mutations found in patients with citrin deficiency
}

\author{
Ayako Tabata $\cdot$ Jian-Sheng Sheng $\cdot$ Miharu Ushikai $\cdot$ Yuan-Zong Song $\cdot$ \\ Hong-Zhi Gao · Yao-Bang Lu · Fumihiko Okumura $\cdot$ Mikio Iijima · \\ Kozo Mutoh · Shosei Kishida · Takeyori Saheki · Keiko Kobayashi
}

Received: 14 December 2007/Accepted: 9 March 2008/Published online: 5 April 2008

(C) The Japan Society of Human Genetics and Springer 2008

\begin{abstract}
Deficiency of citrin, liver-type mitochondrial aspartate-glutamate carrier, is an autosomal recessive disorder caused by mutations of the SLC25A13 gene on chromosome 7q21.3 and has two phenotypes: neonatal intrahepatic cholestatic hepatitis (NICCD) and adult-onset type II citrullinemia (CTLN2). So far, we have described 19 SLC25A13 mutations. Here, we report 13 novel SLC25A13 mutations (one insertion, two deletion, three
\end{abstract}

\footnotetext{
A. Tabata $\cdot$ J.-S. Sheng $\cdot$ M. Ushikai $\cdot$ Y.-Z. Song $\cdot$ H.-Z. Gao $\cdot$ Y.-B. Lu · F. Okumura · M. Iijima - S. Kishida - T. Saheki · K. Kobayashi $(\square)$

Department of Molecular Metabolism and Biochemical Genetics, Kagoshima University Graduate School

of Medical and Dental Sciences, 8-35-1 Sakuragaoka, Kagoshima 890-8544, Japan

e-mail: dodoko12@m.kufm.kagoshima-u.ac.jp

Y.-Z. Song

Department of Pediatrics,

First Affiliated Hospital, Jinan University,

Guangzhou 510632, China

H.-Z. Gao

Department of Brain Surgery,

The Second Clinical College of Fujian Medical University, Quanzhou 362000, China
}

Y.-B. Lu

Department of Biochemistry, Pharmacy College, Hunan University of Traditional Chinese Medicine,

Changsha 410007, China

\section{K. Mutoh}

Department of Pediatrics, Shimada Municipal Hospital, Shizuoka 427-8502, Japan

T. Saheki

Institute for Health Sciences, Tokushima Bunri University,

Tokushima 770-8514, Japan splice site, two nonsense, and five missense) in patients with citrin deficiency from Japan, Israel, UK, and Czech Republic. Only R360X was detected in both Japanese and Caucasian. IVS16ins3kb identified in a Japanese CTLN2 family seems to be a retrotransposal insertion, as the inserted sequence (2,667-nt) showed an antisense strand of processed complementary DNA (cDNA) from a gene on chromosome 6 (C6orf68), and the repetitive sequence (17nt) derived from $S L C 25 A 13$ was found at both ends of the insert. All together, 30 different mutations found in 334 Japanese, 47 Chinese, 11 Korean, four Vietnamese and seven non-East Asian families have been summarized. In Japan, IVS16ins $3 \mathrm{~kb}$ was relatively frequent in 22 families, in addition to known mutations IVS11 + $1 \mathrm{G}>\mathrm{A}$, 851del4, IVS13 + 1G > A, and S225X in 189, 173, 48 and 30 families, respectively; 851 del 4 and IVS16ins $3 \mathrm{~kb}$ were found in all East Asian patients tested, suggesting that these mutations may have occurred very early in some area of East Asia.

Keywords Adult-onset type II citrullinemia (CTLN2) . Aspartate-glutamate carrier (AGC) · Citrin .

Malate-aspartate shuttle .

Neonatal intrahepatic cholestatic hepatitis (NICCD) .

Retrotransposal insertion $\cdot S L C 25 A 13$

\section{Introduction}

Citrin deficiency, which results from mutations in the SLC25A13 gene, is a newly established autosomal recessive disease first reported in Japan and has two major clinical phenotypes: adult-onset type II citrullinemia (CTLN2; MIM \#603471) and neonatal intrahepatic cholestatic hepatitis (NICCD; MIM\#605814) (Kobayashi et al. 
1999; Yasuda et al. 2000; Ohura et al. 2001; Tazawa et al. 2001; Tomomasa et al. 2001; Saheki and Kobayashi 2002; Yamaguchi et al. 2002). The SLC25A13 gene identified by using homozygosity mapping and positional cloning is localized on chromosome $7 q 21.3$, expresses mainly in the liver, and encodes a calcium-binding mitochondrial solute carrier protein with a molecular weight of $74 \mathrm{kDa}(675$ amino acids), designated citrin (Kobayashi et al. 1999). This citrin is localized in the mitochondrial inner membrane and functions as a liver-type calcium $\left(\mathrm{Ca}^{2+}\right)$-stimulated aspartate-glutamate carrier (AGC) by the electrogenic exchange of mitochondrial aspartate for cytosolic glutamate and proton (Palmieri et al. 2001). AGC provides aspartate for the syntheses of urea, protein, and nucleotide in addition to participating in gluconeogenesis from lactate and transporting cytosolic nicotinamide adenine dinucleotide (NADH), reducing equivalents into mitochondria as part of the malate-aspartate shuttle; thus, the deficiency of citrin (liver-type AGC) shows various symptoms.

Patients with CTLN2 (11-79 years of age) suffer from recurring neuropsychiatric symptoms associated with hyperammonemia, including disorientation, delirium, seizures, and coma, that can lead to death from brain edema. Laboratory findings of CTLN2 patients show high blood ammonia; increased plasma citrulline, arginine, threonine to serine ratio, and serum pancreatic secretory trypsin inhibitor (PSTI) levels; and decreased hepatic argininosuccinate synthetase (ASS) activity/protein levels (Saheki et al. 1986, 1987; Kobayashi et al. 1997). No cross-reactive immune materials have been detected in the liver of CTLN2 patients by Western blot analysis with antihuman citrin antibody (Yasuda et al. 2000), indicating that CTLN2 is a citrin deficiency, although the mechanisms of secondary ASS deficiency and stimulated PSTI gene expression in the liver are still unknown. Very few clinical symptoms were known in the neonatal/infantile period of CTLN2 patients. DNA analyses of the SLC25A13 gene have revealed that some neonatal/infantile patients with a type of hepatitis associated with galactosemia, multiple aminoacidemia including citrullinemia, hypoproteinemia, intrahepatic cholestasis, and prolonged jaundice, were homozygotes or compound heterozygotes for the same SLC25A13 mutations as those found in CTLN2 patients (Ohura et al. 2001; Tazawa et al. 2001; Tomomasa et al. 2001). Therefore, we designated them neonatal intrahepatic cholestasis caused by citrin deficiency (NICCD) as a neonatal/infantile phenotype (Saheki and Kobayashi 2002; Yamaguchi et al. 2002).

Until recently, citrin deficiency was thought to be restricted to Japanese subjects. Recently, however, we have found several non-Japanese patients with SLC25A13 mutation: a Palestinian family with duplication of exon 15 (Ben-Shalom et al. 2002), two Israeli families with L598R
(Luder et al. 2006), and two Caucasian families: one in the UK with C489R (Hutchin et al. 2006), and one in the USA with deletion of exon 3 in messenger ribonucleic acid (mRNA) (Dimmock et al. 2007), indicating a wider distribution of citrin deficiency. Some of the 13 SLC $25 A 13$ mutations identified in Japanese patients with citrin deficiency were found in Chinese, Korean, and Vietnamese patients from Taiwan, China, Korea, Australia, France, Czech Republic, and USA (Hwu et al. 2001; Kobayashi et al. 2003; Yang et al. 2003; Lu et al. 2005; Liu et al. 2006; Kim et al. 2006; Sheng et al. 2006; Lee et al. 2006; Yeh et al. 2006; Tsai et al. 2006; Song et al. 2006, 2007; Ko et al. 2007). These results suggest that the mutations go back to a common ancestor and prevail at least in East Asia. On the other hand, we have found that the frequency of carriers (heterozygotes with the mutated SLC25A13 gene in one allele) is very high in the East Asian population: China (1/65), especially south of China (1/48); Japan (1/69), and Korea (1/112) (Saheki and Kobayashi 2002; Kobayashi et al. 2003; Lu et al. 2005).

So far, worldwide, we have identified 18 different mutations in the SLC25A13 gene of patients with citrin deficiency (Kobayashi et al. 1999; Yasuda et al. 2000; Yamaguchi et al. 2002; Ben-Shalom et al. 2002; Lu et al. 2005; Takaya et al. 2005; Luder et al. 2006; Hutchin et al. 2006; Sheng et al. 2006; Ko et al. 2007) and a mutationdeleted exon 3 in mRNA but not identified yet in the SLC25A13 gene (Dimmock et al. 2007). In this study, we report 13 novel mutations, including a retrotransposal insertion identified in the SLC25A13 gene of CTLN2 and NICCD patients, and we summarize the frequency and distribution of all 30 SLC25A13 mutations.

\section{Subjects and methods}

\section{Subjects}

CTLN2 patients have been diagnosed on the basis of wellestablished criteria, including symptoms and laboratory findings such as high blood ammonia, increased plasma/ serum citrulline, arginine, ratio of threonine to serine and PSTI levels, and decreased hepatic ASS activity levels (Saheki et al. 1986, 1987; Kobayashi et al. 1997). NICCD patients with various transient symptoms have been found or suspected by newborn screening in association with galactosemia and/or methioninemia or among those who suffered from persistent infantile cholestatic jaundice and multiple aminoacidemias, including elevated citrulline, methionine, threonine, tyrosine, and arginine levels at 1-4 months of age (Tazawa et al. 2004; Ohura et al. 2007). Other features shown in NICCD patients are hypoproteinemia, growth retardation, hypoglycemia, fatty liver, mild 
liver dysfunction, and/or high levels of plasma $\alpha$-fetoprotein. Most NICCD patients show symptoms that ameliorate by 1 year of age, and more than 10 years or even several decades later, some patients develop CTLN2 (Kasahara et al. 2001; Tomomasa et al. 2001; Saheki and Kobayashi 2002). Many individuals with CTLN2 are fond of protein/ lipid-rich foods and have an aversion to sugar/carbohydraterich foods. As we recently found that children show strong food preferences starting around 1-2 years of age after NICCD symptoms have disappeared, we use this as a diagnostic marker of citrin deficiency. The clinical data from CTLN2 or NICCD patients used for identifying novel SLC25A13 mutations have been described (Oshiro et al. 2002; Waki et al. 2004; Ikeda et al. 2004; Yazaki et al. 2005) and will be reported elsewhere. Samples such as liver specimens and/or cultured fibroblast cells were obtained with the approval of the Institutional Ethics Review Board in each country or area.

\section{Mutation detection}

To identify unknown SLC25A13 mutations, we mainly used sequencing analysis of DNA fragments amplified by reverse transcriptase polymerase chain reaction (RT-PCR) and/or genomic DNA-PCR, as described previously (Kobayashi et al. 1999; Yasuda et al. 2000; Yamaguchi et al. 2002; Ben-Shalom et al. 2002; Lu et al. 2005; Takaya et al. 2005). Total RNA was isolated from cultured fibroblast cells or autopsied/biopsied liver specimens, and the firststrand complementary DNA (cDNA) was synthesized using oligo-(dT) ${ }_{12-18}$ and $\mathrm{M}-\mathrm{MuLV}$ reverse transcriptase. The entire coding portion of SLC25A13 mRNA was amplified with suitable primer sets as described previously (Kobayashi et al. 1999). For genomic DNA-PCR, regions (average size about 500 bp) containing 18 exons each were individually amplified using oligonucleotides derived from intronic sequences flanking each exon as PCR primers. The amplified PCR products of cDNA and/or genomic DNA were separated on agarose gels, extracted from gel with QIA Quick Gel Extraction Kit (Qiagen Inc., CA, USA), and sequenced by means of the Dye Terminator Cycle Sequencing Ready Reaction on an ABI-310 Genetic Analyzer (PE Applied Biosystems, Foster City, CA, USA).

To find the large insertion mutation in the P557 family with CTLN2, haplotyping using a microsatellite marker, D7S1812, located in intron 15 of the SLC25A13 gene, was performed according to the GeneScan method, as described previously (Kobayashi et al. 1999). Two single nucleotide polymorphisms (SNPs), rs1016968 in intron 13 (SNP15) and rs2269781 in intron 14 (SNP22) of the SLC25A13 gene (Fig. 1a), were detected by PCR/restriction fragment length polymorphism (RFLP) with primers 15F: 5'-TTTCCATCTTTTCCCTTCTTGG-3' and 15R:
5'-GCGCTGCAGCCTACAGATCA-3' and restriction enzyme Tru9I or AseI, and by direct sequencing of PCR product with primers 22F: 5'-TCAACCTAGACTTGTAT ACCCT-3' and 22R: 5'-TCTTGGCTTCCCCCAAGCAA $-3^{\prime}$, respectively. Long-range PCR was performed according to the manufacturer's instructions using Takara LA $\mathrm{Taq}^{\mathrm{TM}}$ polymerase (Takara Bio, Shiga, Japan) with primer set "c" shown in Fig. 1b (IVS15F: 5'-CACAGTGGGT TTCTAAGCATTT-3' and Ex18R: 5'-TGCTTCATTCCCA GGAGGGA-3'). DNA diagnosis for mutation [XIII]:P632L was performed PCR-RFLP with primers IVS17F: $5^{\prime}-\mathrm{CTG}$ ATGAGAATGTATCAACTCC-3' and Ex18Bm: $5^{\prime}-\mathrm{GCCC}$ CCAACGTGATCAGGAC- $-3^{\prime}$, modified base is underlined, and Dde I. To detect the antisense sequence of C6orf68 (NM_138459) inserted in the cDNA of P557, RT-PCR was performed using a primer set "d" shown in Figs. $1 \mathrm{~b}$ and 2: Ex14F: 5'-TCAGTGCTCTGTCTGTCG TG-3' and MGC2331R: 5'-CTTCCCTCACTGCTGATT CTT-3'. The downstream nucleotide (nt) sequence of the mutated transcript with new exon 17 (see Figs. 2 and 3) was confirmed by using the $3^{\prime}$-RACE System (Gibco BRL, Tokyo, Japan) and SLC25A13-specific primer Ex14F. The $3^{\prime}$-RACE products were sequenced by using the method described above.

The scores of splice-site prediction were calculated by means of the software provided by http://www.fruitfly.org/ cgi-bin/seq_tools/splice.pl for splice site prediction (SSP) and http://genes.mit.edu/burgelab/maxent/Xmaxentscan_ scoreseq.html for Maximum Entropy (MaxEnt). The amino acid sequence of human citrin (AAD38501) was aligned comparatively with homologous proteins from nine other eukaryotic species (chimpanzee: XP_527824, macaque: Q8HXW2, horse: XP_001494475, cattle: XP_872377, dog: XP_852644, mouse: AAF21426, rat: XP_001054092, chicken: NP_001012967 and Xenopus: AAI21260), with human aralar (NP_003696) and the homologous protein from six other species (orangutan: CAH90932, monkey: XP_001085208, cattle: NP_001094664, dog: XP_535962, mouse: NP_766024 and Xenopus: AAI23038), and with homologous protein from C. elegans (Q21153).

\section{DNA diagnosis}

For East Asian patients, 13 known mutations were screened according to the methods described previously by using GeneScan/SNaPshot and/or PCR/gel running (Yamaguchi et al. 2002; Lu et al. 2005; Takaya et al. 2005). After identification of novel mutations, we established the DNA diagnosis methods for each mutation. The detection of 13 novel mutations identified in this study was performed using genomic DNA by a combination of PCR (or modified PCR) with or without restriction enzyme digestion, or by direct sequencing. DNA samples were obtained according 
[a]

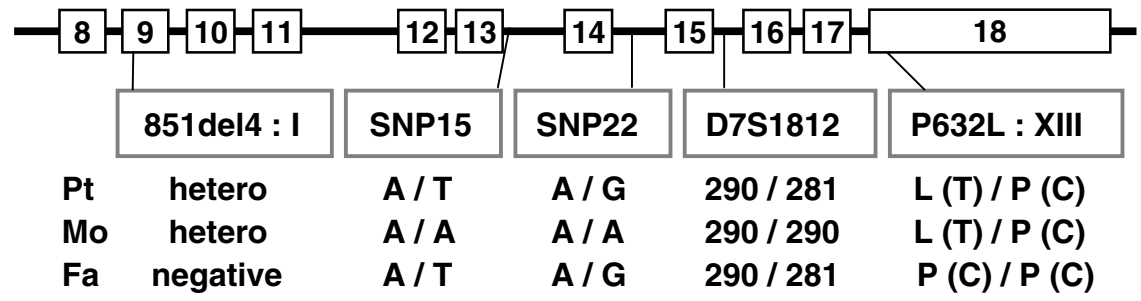

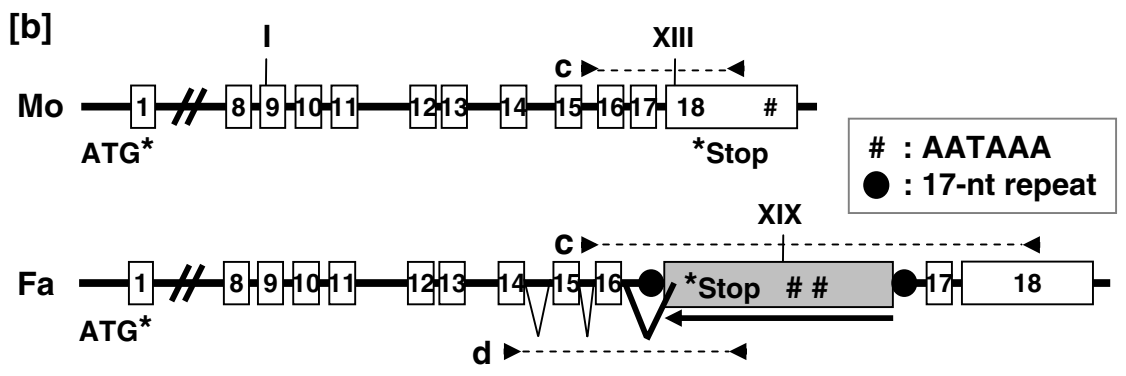

[c]

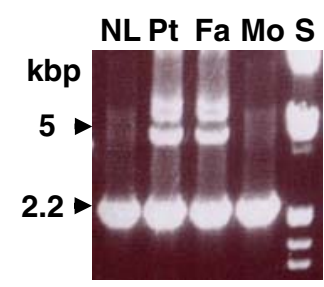

[d]

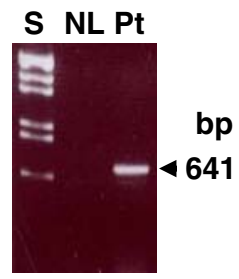

[e]

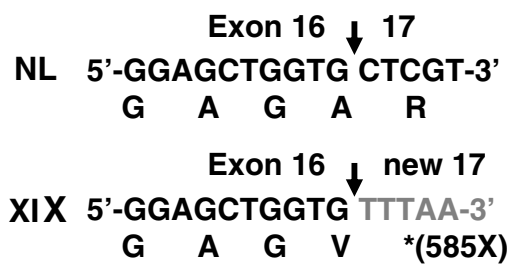

Fig. 1 Identification of a novel retrotransposal insertion mutation, [XIX]:IVS16ins3kb, in an adult-onset type II citrullinemia (CTLN2) (P557) family. a DNA diagnosis of two mutations, [I]:851del4 and [XIII]:P632L, and haplotyping analysis of three polymorphisms, SNP15, SNP22 and microsatellite D7S1812. Numbers in box 8-18 show exons in the SLC25A13 gene. Pt patient, Mo mother, Fa father. b Schematic representation of the mutated alleles from the parents of P557. The shaded box in the paternal allele with the mutation [XIX]:IVS16ins $3 \mathrm{~kb}$ is the inserted antisense strand sequence of C6orf68 cDNA (see Fig. 2), and the lower arrow shows the direction

to institutional guidelines in each country. DNA was prepared using standard methods from blood, cells, or tissues of patients and from blood of their family members and unrelated volunteer individuals as controls after informed consent was obtained. This study was approved by the Committee for Ethics of Kagoshima University Faculty of Medicine and was carried out in accordance with the principles of the Declaration of Helsinki.

\section{Results}

Identification of a novel retrotransposal insertion mutation ([XIX]:IVS16ins $3 \mathrm{~kb}$ )

A Japanese patient (P557, 16 years of age) was diagnosed as CTLN2 by clinical and biochemical studies and treated of insert. c Gel running of long and accurate polymerase chain reaction (LA-PCR) product using primer set "c" (IVS15F and Ex18R) shown in b, from intron 15 to exon 18 (2,201 bp: IVS151321_Ex18 + 261) of genomic DNA in a CTLN2 family (Pt patient, $F a$ father, Mo mother) and control (NL). $S$ size marker of DNA. d Gel running of reverse transcriptase (RT)-PCR using primer set "d" (Ex14F and MGC2332R) shown in b, from exon 14 to inserted sequence (641 bp: see Fig. 2). e Predicted amino acid sequence of the allele with mutation [XIX]

with partial liver transplantation from her mother (Waki et al. 2004). Before the operation, DNA diagnosis for known SLC25A13 mutations revealed that she was a compound heterozygote with two different mutations, [I]:851del4 from the maternal allele and [?]:unknown from the paternal allele. By sequencing analysis of PCR product with $664 \mathrm{bp}$ from intron 16 to exon 18 (IVS1635_Ex18 + 261), a base substitution from $\mathrm{C}$ to $\mathrm{T}$ at 1895 ([XIII]:P632L) was detected in P557 homozygously and in the mother heterozygously but not in the father (data not shown). However, DNA diagnosis for the mutation [XIII] using a primer set of IVS17F and Ex18Bm after the detection of a novel mutation in the paternal allele showed in P557 heterozygously (Fig. 1a). The sequencing of RTPCR product from exon 9 to exon 18 (871-2055) using hepatic cDNA of P557 showed homozygous for two mutations, [I] and [XIII] (data not shown), suggesting that 
5'-GTATGCCTGCAGCATCT-(Exon 16)-TGGAAGGGAGCTGGTG gtatggaaa taatgtgttcttaactaactctttggtatcaggtaaattttaaaatatctaattatatctgt gatttctccatttttt

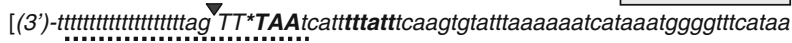
tccaaagttgaaacatttattcttcatagcttcagaatttaacaaccaattgtagaccatgctttccaaatccag tcttcttgctattttcaaaacttctgagatctagtattaaactgctccattctaaatgtatagttttagataagtatt gtacacttgttgataagggtttctgaaagcagtctatcaaatataaagaatggtttctatctaagaatcagca gtgagggaagaaatattaaacacctatcaagaaatcaattattcattttaaaaataacagaaccagtgctg ctctctgtcataaaagagaacatgtaaaatttatttttatagactttggtaatattttattcccccacagaggcctt caatcctacttaaagatattttacacacagtaaccatcaggatttactgagtaaaaatctcaggtattaacca tgcccctaaaatgtgctattccaaagaggaacaggttactttgaggaaaaaagctgccttggtaacttccc tcaaatgtttattttaAATAAAaatggttgatggaaatattttttaaaagaactttgggtataatatggcatac tgcccatcaaacaaaaaaggaAATAAAactttctttccatt ${ }^{\wedge}$ at^ ${ }^{\wedge}$ aataagtttccacctttactatcaa gattacaacttattgaccttttatgcttgcttggt--(1740 bp)--C6orf68 cDNA--gcagcgcgacgg ctttttatccgcccctgcggccggcgcgggccatcgctccgcgtccccccgccccccgagcccgaacccc tttccactgccaacacctcacctcgcccccgccgccatcttcctcctcccttggcagccccgcccccc-(5')] gatttctccatttttt aaag 'CTCGTGTATTTCG-(Exon 17)-ATTTTGGAGGAGT-3'

Fig. 2 Sequence of exon16-intron16-exon17 in the SLC25A13 gene and the inserted antisense strand complementary DNA (cDNA) processed from gene on chromosome 6 (C6orf68). The [XIX]:IVS16ins3kb found in paternal allele of an adult-onset type II citrullinemia (CTLN2) patient had an inserted antisense strand C6orf68 cDNA (the sequence of 2,667-nt shown by italic) with 17-nucleotide (nt) repeat (shaded boxes), whose sequence is from -21 to -5 of intron 16 between +71 and -4 position of intron 16 in the SLC25A13 gene, as shown in Fig. 1b. As a result, the new transcription termination $(\wedge)$ and new $3^{\prime}$ side of splicing site (closed arrowhead and dotted underline) were created. The new messenger ribonucleic acid (mRNA) from the insertion mutation caused a frame shift from codon 584, leading to premature termination (TAA from the inserted sequence) at codon 585 in citrin protein, instead of mature termination at codon 675. The sequence of primer MGC2331R used in Fig. 1d is underlined. Open arrowheads are $5^{\prime}$ and $3^{\prime}$ side of splicing sites in intron 16 of the normal SLC25A13 gene

the unknown mutation from the paternal allele in the 577 family is located on the $3^{\prime}$ side of the SLC25A13 gene. The finding that both [I] and [XIII] mutations are from the maternal allele (see Fig. 1b) indicates that [XIII]:P632L has no effect on the citrin function, because mutation [I]:851del4 produces a truncated form, R284fs(286X).

Haplotype analysis with SNP15, SNP22, and D7S1812 revealed that P557 had alleles from both parents in the regions tested (Fig. 1a). To define the paternal mutation, we performed long-range PCR with genomic DNA of the 557 family members from intron 15 to exon 18 (primer set "c" in Fig. 1b), and detected a PCR product of larger size in P557 and her father but not in her mother or control (Fig. 1c). By sequencing, we found that the inserted sequence (2,667-nt) showed an antisense strand of processed cDNA from a gene on chromosome 6 (C6orf68: NM_138459) and that the repetitive sequence (17-nt) derived from the SLC25A13 gene was found at both ends of the insert (Fig. 2), suggesting that the [XIX]:IVS16ins3kb (Table 1) is a retrotransposal insertional mutation. As shown in Figs. 1b and 2, the direction of the inserted C6orf68 cDNA is reverse to the $S L C 25 A 13$ transcript, and two poly(A) additional signals, AATAAA, are present

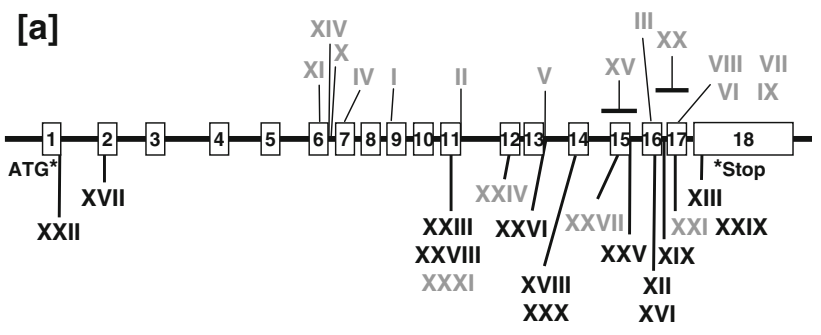

[b]

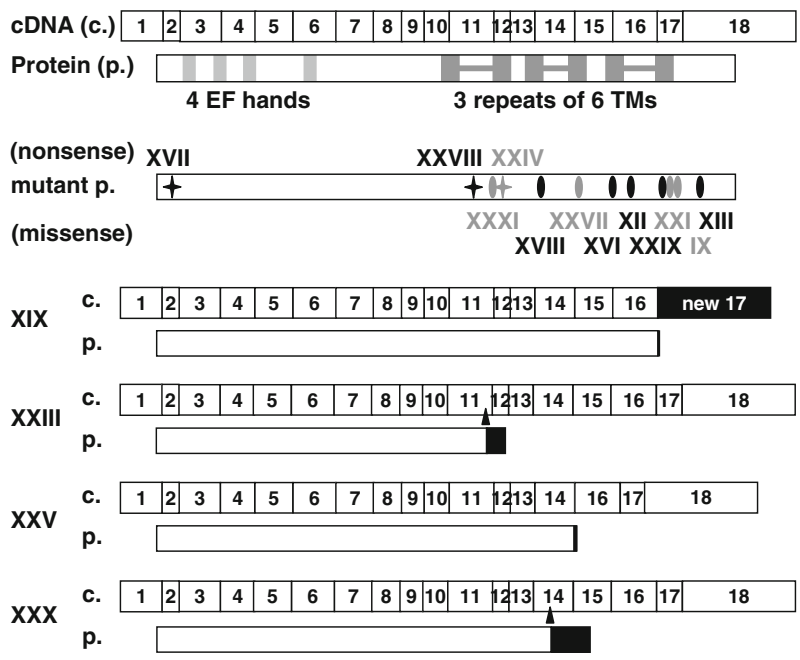

Fig. 3 Summary and location of 30 mutations in the SLC25A13 gene (a), and schematic structures of SLC25A13 complementary DNA (cDNA) and citrin protein predicted from novel mutations (b). Characteristics of mutations [I]-[XXXI] are shown in Table 1. Black and gray letters show the novel and known mutations, respectively. TM mitochondrial transmembrane, filled star nonsense, filled oval missense, filled triangle, 1-bp deletion mutation. Closed boxes represent the regions of abnormal sequence in cDNA $(c)$ and protein $(p)$

within the inserted sequence, indicating the termination of RNA synthesis in the insert. The new cryptic splice site (closed arrowhead in Fig. 2) is predicted in the insert from the high score (1.00) of the acceptor site predictions by the SSP method. We confirmed that the mutated mRNA molecule with new exon 17 (Figs. 2 and 3b) was transcribed in the liver of P557 by RT-PCR with primer set "d" (Figs. 1b,d). Furthermore, $3^{\prime}$-RACE revealed that the major transcription termination at 17-/19-nt downstream second AATAAA (" $\wedge$ " in Fig. 2) resulted from the use of AATAAA located downstream out of two AATAAA sites (Fig. 2). On the other hand, Western blot analysis showed that the truncated protein with mutation [XIX], A584V (585X) as shown in Fig. 1e, was not detected in the liver of P557 ([I]/[XIX]) nor in another CTLN2 patient (P92) with homozygous [XIX] (data not shown).

After identifying mutation [XIX] in a Japanese family with CTLN2 (P557), to detect both [XIX]:IVS16ins3kb and [XX]:Ex16 + 74_IVS17-32del516 (Takaya et al. 2005), 
Table 1 SLC25A13 mutations/variations found in patients with citrin deficiency

\begin{tabular}{|c|c|c|c|}
\hline \multicolumn{2}{|c|}{ Mutation (location) } & \multirow{2}{*}{$\begin{array}{l}\text { Nucleotide change } \\
\text { :g./c.851_854delGTAT }\end{array}$} & \multirow{2}{*}{$\begin{array}{l}\text { Amino acid change } \\
\text { :p.R284fs }(286 \mathrm{X})\end{array}$} \\
\hline $\mathrm{I}^{\mathrm{a}}$ & :851del4 (Ex9) & & \\
\hline $\mathrm{II}^{\mathrm{a}}$ & :g.IVS11 + 1G > A & :c.1019_1177del & :p.340_392del \\
\hline $\mathrm{III}^{\mathrm{a}}$ & :1638ins23 (Ex16) & :g./c.1638_1660dup & :p.A554fs(570X) \\
\hline $\mathrm{IV}^{\mathrm{a}}$ & :S225X (Ex7) & :g./c.674C > A & :p.S225X \\
\hline $\mathrm{V}^{\mathrm{a}}$ & :g.IVS13 + 1G > A & :c.1231_1311del & :p.411_437del \\
\hline $\mathrm{VI}^{\mathrm{b}}$ & :1800ins1 (Ex17) & :g./c.1799-1800insA & :p.Y600X \\
\hline $\mathrm{VII}^{\mathrm{b}}$ & :R605X (Ex17) & :g./c.1813C > T & :p.R605X \\
\hline $\mathrm{VIII}^{\mathrm{c}}$ & :E601X (Ex17) & :g./(c.)1801G > T & :p.E601X \\
\hline $\mathrm{IX}^{\mathrm{c}}$ & :E601K (Ex17) & :g./(c.)1801G > A & :p.E601K \\
\hline $\mathrm{X}^{\mathrm{d}}$ & :g.IVS6 + 5G > A & :c. not detectable & : \\
\hline $\mathrm{XI}^{\mathrm{d}}$ & :R184X (Ex6) & :g./(c.)550C > T & :p.R184X \\
\hline XII* & :T546M (Ex16) & :g./c.1637C > T & :p.T546M \\
\hline XIII* & :P632L (Ex18) & :g./c.1895C > T & :p.P632L \\
\hline $\mathrm{XIV}^{\mathrm{d}}$ & :g.IVS6 + 1G >C & :c.IVS6(1789bp)ins & :p.A206fs(212X) \\
\hline$X V^{e}$ & :g.Ex15dup (IVS14_15) & :c.1453_1591dup & :p.M532fs(560X) \\
\hline XVI* & :G531D (Ex16) & :g.1592G > A & :p.G531D \\
\hline XVII* & :E16X (Ex2) & :g./c.46G > T & :p.E16X \\
\hline XVIII* & :T446P (Ex14) & :g./c.1336A > C & :p.T446P \\
\hline XIX* & :g.IVS16ins3kb & :c. aberrant RNA & :p.A584fs(585X) \\
\hline$X X^{f}$ & :g.Ex16 + 74_IVS17-32del516 & :(c. aberrant RNA) & :p.Q556fs(565X) \\
\hline $\mathrm{XXI}^{\mathrm{g}}$ & :L598R (Ex17) & :g./c.1793T > G & :p.L598R \\
\hline XXII* & :g.Ex1-1G > A (Ex1) & :c. not detectable & : \\
\hline XXIII* & :1146delA (Ex11) & :g./c.1146delA & :p.R383fs(407X) \\
\hline $\mathrm{XXIV}^{\mathrm{h}}$ & :Q397X (Ex12) & :g./c.1189C > T & :p.Q397X \\
\hline $\mathbf{X X V *}$ & :g.IVS15 + 1G > T & :c.1453_1591del & :p.G485fs(491X) \\
\hline XXVI* & :g.IVS13 + 2T > G & :c. not detectable & : \\
\hline XXVII ${ }^{i}$ & :C489R (Ex15) & :g./c.T1465C & :p.C489R \\
\hline XXVIII* & :R360X (Ex11) & :g./c.1078C > T & :p.R360X \\
\hline XXIX* & :R588Q (Ex17) & :g./c.1763G > A & :p.R588Q \\
\hline $\mathbf{X X X} *$ & :1374/5delG (Ex14) & :g./c.1374 or 1375delG & :p.A459fs(507X) \\
\hline $\mathrm{XXXI}^{\mathrm{j}}$ & :G393S (Ex11) & :g./(c.)1177G > A & :p.G393S \\
\hline
\end{tabular}

a-j These mutations have been described previously by ${ }^{\mathrm{a}}$ Kobayashi et al. (1999), ${ }^{\mathrm{b}}$ Yasuda et al. (2000), ${ }^{\mathrm{c}}$ Yamaguchi et al. (2002), ${ }^{\mathrm{d}} \mathrm{Lu}$ et al. (2005), ${ }^{\mathrm{e}}$ Ben-Shalom et al. (2002), ${ }^{\mathrm{f}}$ Takaya et al. (2005), ${ }^{\mathrm{g}}$ Luder et al. (2006), ${ }^{\mathrm{h}}$ Sheng et al. (2006), ${ }^{\mathrm{i} H u t c h i n}$ et al. (2006), ${ }^{\mathrm{j}} \mathrm{Ko}$ et al. (2007)

* Novel mutations/variations found in this study are indicated by bold letters. Nucleotide numbering based on complementary DNA (cDNA) sequence (GenBank: NM_014251) begins with +1 as the A of the ATG initiation codon

we established a DNA diagnosis method using agarose gel electrophoresis of PCR product amplified with LA-Taq polymerase and primer set (Ex16F: 5'-GTATGCCTGC AGCATCTTTAG-3' and Ex18-3'R: $5^{\prime}$-TGCTTCATTCCC AGGAGGGA-3'). This diagnostic method revealed that mutation [XIX] was found relatively frequent in East Asia including Japan, Korea, China, Taiwan, and Malaysia, as summarized in Table 2. Clinical data of some patients with mutation [XIX] have been described (Waki et al. 2004; Tazawa et al. 2004; Liu et al. 2006; Kim et al. 2006; Tokuhara et al. 2007; Ko et al. 2007) and will be reported (Y.-Z Song et al., D.-M Niu et al.; M.-K Thong et al., manuscript in preparation). On the other hand, we detected a heterozygous carrier with mutation [XIX] in 1,372 Japanese controls but no carrier with [XIX] in 2,641 Chinese or 2,228 Korean controls.

Three novel splice-site mutations ([XXII]:Ex1-1G $>$ A, $[\mathrm{XXV}]: \operatorname{IVS} 15+1 \mathrm{G}>\mathrm{T},[\mathrm{XXVI}]: \mathrm{IVS} 13+2 \mathrm{~T}>\mathrm{G})$

By DNA diagnosis for known mutations, we found that one Japanese CTLN2 patient (P857) was [II]/[?] (Ikeda et al. 2004; Yazaki et al. 2005). Western blotting of the liver specimens revealed that P857 is a citrin deficiency (data not shown). RT-PCR detected only one band of mRNA from an allele with mutation [II]:IVS11 + IG $>$ A 
Table 2 Frequency of the 30 SLC25A13 mutations found in patients with citrin deficiency

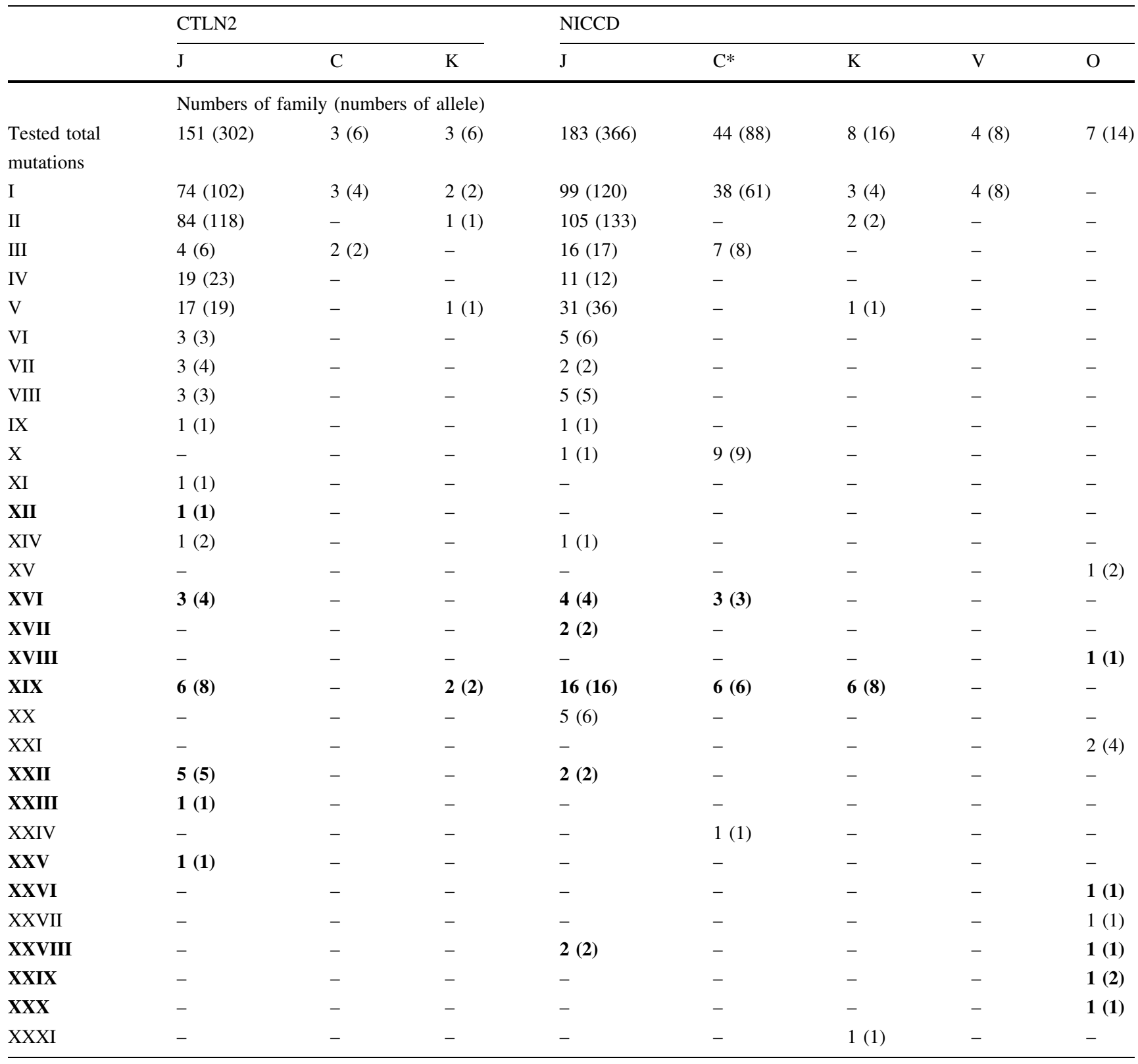

Of families listed, most of them were diagnosed at Kagoshima University in Japan, and 5 of 44 Chinese ( $\left.\mathrm{C}^{*}\right)$ neonatal intrahepatic cholestatic hepatitis (NICCD) families were diagnosed in Taiwan (Yeh et al. 2006; Lee et al. 2006)

Novel mutations found in this study are indicated by bold letters. CTLN2 adult-onset type II citrullinemia, $J$ Japanese, $C$ Chinese, $K$ Korean, $V$ Vietnamese, $O$ others (non-East Asian)

(mRNA molecules deleted exon 11). Sequencing all 18 exons using genomic DNA, we found a base substitution from $\mathrm{G}$ to $\mathrm{A}$ at the $3^{\prime}$ end of exon 1 ([XXII]:Ex1-1G $>\mathrm{A}$ ), but no change in amino acid sequences. However, the scores of predicted splicing sites, SSP and MaxEnt, decreased in mutation [XXII] from 0.95 to $<0.40$ and from 9.24 to 2.93 , respectively.

[XXV]:IVS15 $+1 \mathrm{G}>\mathrm{T}$ found in a Japanese CTLN2 patient (P474: [III]/[?]) produced a deletion of exon 15 (139 bp) in mRNA (data not shown), causing a frame shift and leading to a premature termination codon in exon 16 and a truncated form of the citrin protein G485fs(491X), as shown in Fig. 3b and Table 1. The SSP and MaxEnt scores decreased in mutation [XXV] from 0.98 to $<0.40$ and from 10.10 to 1.59 , respectively. [XXVI]:IVS13 $+2 \mathrm{~T}>\mathrm{G}$ from paternal allele was found in genomic DNA of an Ashkenazi Jewish NICCD patient (P709) from Israel, but RT-PCR/sequencing of cDNA prepared from the cultured fibroblast cells of P709 showed homozygous [XVIII]:T446P mutation from maternal allele, suggesting 
Fig. 4 Alignment of human citrin (hum-c), aralar (hum-a), and their homologous protein in the mutated areas. Chm chimpanzee, Mac macaque, Hor horse, Cat cattle, Mou mouse, Chk chicken, X.T Xenopus tropicalis, Ora orangutan, Mon monkey, C. Ele Caenorhabditis elegans. $T M$ denotes mitochondrial transmembrane (shaded area). The black and gray letters show the novel and known mutations, respectively
XXXI:G3935

Hum-c 388 FGLYRGLLPQLLGVAPEKAIKLTVNDFVRDKFMHKDGSVPLAAEILAGGCAGGSQVIFTNPLEIVKIRLQVAGE

XVIII:T446P Chm-c 389 FGL YRGL LPOLL GVAPEKA IKL TVNDFVRDKFMHKDGSVPL AAEILAGGCAGGSQVTFTNPIETVKIRL QVAGE $\mathrm{Mac}^{-\mathrm{c}} 388$ FGLYRGLLPQLLGVAPEKAIKL TVNDFVRDKFMHKDGSVPLAAEILAGGCAGGSOVIFTNPLEIVKIRLQVAGE $\mathrm{Mac}^{-\mathrm{c}} 388$ FGLYRGLPQLLGVAPKATK $\begin{array}{lll}\text { Hor-c } & 386 & \text { FGLYRGLLPQLLGVAPEKAIKLTVNDFVRDKFMHKDGSVPLAAE ILAGGCAGGSQV IFTNPLEIVKIRLQVAGE } \\ \text { Cat }^{-c} 388 \text { FGLYRGLLPQLGVAPEKA IKLTVNDFVRDKFMRRDGSVPLAAEILAGGCAGGSQV IFTNPLEIVKIRLQVAGE }\end{array}$ $\begin{array}{lll}\text { Cat-c } 388 & \text { FGLYRGLLPQLLGVAPEKAIKLTVNDFVRDKFMRRDGSVPLAAEILAGGCAGGSQV IFTNPLEIVKIRLQVAGE } \\ \text { Dog-c } 387 & \text { FGLYRGLLPQLLGVAPEKAIKLTVNDFVRDKFMRKDGSVPLAAEILAGGCAGGSQVIFTNPLEIVKIRLQVAGE }\end{array}$ Mou-c 389 FGLYRGLLPQLLGVAPEKA IKLTVNDFVRDKFMHKDGSVPLLAEIFAGGCAGGSQV IFTNPLE IVKIRLQVAGE Rat-c 389 FGLYRGLLPQLLGVAPEKAIKLTVNDFVRDKFMHKDGSVPLLAEIFAGGCAGGSQVIFTNPLEIVKIRLQVAGE Chk-c 387 FGLYRGLLPQLLGVAPEKAIKLTVNDFVRDKFMSKDGSVPLAAEILAGGCAGGSQVIFTNPLEIVKIRLQVAGE $X$. T-c 109 FGLYRGLLPQLL GVAPEKAIKL TVYDFVRDKFTTNEGS IPL AEIL AGGCAGGSQVIFTNPLEIVKIRLQVAGK Hum-a 386 FGLYRGLIPQLIGVAPEKAIKLTVNDFVRDKFTRRDGSVPLPAEVLAGGCAGGSQVIFTNPLEIVKIRLQVAGE Hum-a 386 FGLIRGLIPQLIGVAPEKAIKLTVDFVRFTRDGSVPLPAEVLAGGCAGGSQVIFTNPLEIVKIRLQVAGE $\begin{array}{lll}\text { Ora-a } & 386 & \text { FGLYRGLIPQLIGVAPEKAIKLTVNDFVRDKFTRRDGSVPLPAEVLAGGCAGGSQV IFTPPLEIVKIRLQVAGE } \\ \text { Mon-a } 386 \text { FGLYRGLIPQLIGVAPEKAIKLTVNDFVRDKFTRRDGSVPLPAEVLAGGCAGGSQVIFTNPLEIVKIRLQVAGE }\end{array}$ Cat-a 384 FGLYRGLIPQLIGVAPEKAIKLTVNDFVRDKFTRRDGSIPLLAEILAGGCAGGSQVIFTNPLEIVKIRLQVAGE Dog-a 386 FGLYRGLIPQLIGVAPEKAIKLTVNDFVRDKFTRRDGSIPLLAEILAGGCAGGSQVIFTNPLEIVKIRLQVAGE Mou-a 386 FGLYRGLIPQLIGVAPEKAIKLTVNDFVRDKFTKRDGSIPLPAEILAGGCAGGSQVIFTNPLEIVKIRLQVAGE X. T-a 210 FGLYRGLLPQLVGVAPFKAIKLTVNDFVRDKFTQKDGS IPLLAEIMAGGCAGGSQVIFTNPLEIVKIRLQVAGE C. Ele 429 LGLYRGLLPQIVGVAPEKAIKLTUNDYMRDKFT-KDGKIPLYGEIIAGGTGGUCQVVFTNPLEIVKIRLQTAGE TM2 TM3

XXVII:C489R

XVI:G531D XII:T546M $\nabla$

Hum-c $^{-c} 477$ LGFFGIYKGAKACFLRDIPFSAIYFPCYAHVKASFANEDGQVSPGSLLLAGAIAGMPAASLVTPADVIKTRLQV $\mathrm{Chm}^{-\mathrm{c}} 478$ LGFFGIYKGAKACFLRD IPFSAIYFPCYAHVKASFANEDGQVSPGSLLLAGAIAGMPAASLVTPADVIKTRLQV $\mathrm{Mac}^{-\mathrm{c}} 477$ LGFFGIYKGAKACFLRDIPFSAIYFPCYAHARASFANEDGQVSPGSLLLAGATAGMPAASLVTPADVIKTRLQV Hor-c 465 LGFFGIYKGAKACFL RD IPFSA IYFPCYAHVKASFANEDGQISPGSLLLAGAAGGMPASLVTPADVIKTRLQV Hor-c 465 LGFFGIYKGAKACFLRD IPFSAIYFPCYAHVKAALANEDGQ ISPGSLLLAGAIAGMPAASLVTPADVIKTRLQV Cat-c 477 LGFFGIYKGAKACFLRD IPFSAIYFPCYAHVKAALANEDGQISPGSLLLAGAIAGMPAASLVVTADVI IKTRLQV
Dog-c 476 LGFFGIYKGAKACFLRD IPFSAIYFPCYAHVKASFANEDGQISPGSLLLAGAIAGMPAASLVTPADVIKTRLQV Dog-c 476 LGFFGIYKGAKACFLRD IPFSAIYFPCYAHVKASFANEDGQISPGSLLLAGAIAGMPAASLVTPADVIKTRLQV
Mou-c 478 LGFFGIYKGAKACFLRDIPFSAIYFPCYAHVKASFANEDGQVSPGSLLLAGAIAGMPAASLVTPADVIKTRLQV Rat-c 478 LGFFGIYKGAKACFLRDIPFSAIYFPCYAHVKASFANEDGQVSPGSLLLAGAIAGMPAASLVTPADVIKTRLQV Chk-c 476 LGFFGLYKGAKACFLRDIPFSAIYFPCYAHLKASFANEDGRVSPGNLLLAGSIAGMPAASLVTPADVIKTRLQV X. T-c 198 LGFFGLYKGAKACFLRDIPFSAIYFPCYAHMKASFANEDGRVSPGYLLLAGAIAGMPAASLVTPADVIKTRLQV Hum-a 475 LGIFGLYKGAKACFLRDIPFSAIYFPVYAHCKLLLADENGHVGGLNLLAAGAMAGVPAASLVTPADVIKTRLQV Hum-a 475 LGIFGLYKGAKACFLRDPPFSAIYFPVYAHCKLLLADENGHVGGLNLLAAGAMAGVPAASLVTPADVIKTRLQV Ora-a 475 LGIFGLYKGAKACFLRDIPFSAIYFPVYAHCKLLLADENGHVGGLNLLAAGAMAGVPAASLVTPADVIKTRLQV Mon-a 475 LGIFGLYKGAKACFLRDIPFSAIYFPVYAHCKLLLADENGHVGGLNLLAAGAMAGVPAASLVTPADVIKTRLQV
Cat-a 473 LGLFGLYKGAKACFLRDIPFSAIYFPVYAHCKLLLADENGHVGG INLLAAGAMAGVPAASLVTPADVIKTRLQV Cat-a 473 LGLFGLYKGAKACFLRD IPFSAIYFPVYAHCKLLLADENGHVGGINLLAAGAMAGVPAASLVTPADVIKTRLQV Dog-a 475 LGLFGLYKGAKACFLRD IPFSAIYFPVYAHCKLLLADENGHVGG INLLAAGAMAGVPAASLVTPADVIKTRLQV Mou-a 475 LGLFGLYKGAKACFLRDIPFSAIYFPVYAHCKLLLADENGRVGG INLLTAGALAGVPASLVTPADVIKTRLQV X. T-a 299 LGILGLYKGAKACFLRDIPFSAIYFPVYAHCKTLLADEQGHIGALQLLTAGAIAGVPAASLVTPADVIKTRLQV C. Ele 518 LGFLGLYKGSRACFLRD IPFSAIYFPAYAHAKLASADEDGMNSPGTLFASAFIAGVPAAGLVTPADVIKTRLQV

XIII:P632L

XXIX:R588Q XXI:L598R IX:E601K

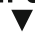

Hum-c 577 ALWKGAGARVFRSSPQFGVTLLTYELLQRWFYIDFGGVKPMGSEPVPKSRI-NLPAPNPDHVGGY $\mathrm{Chm}^{-\mathrm{c}} 578$ ALWKGAGARVFRSSPQFGVTLLTYELLQRWFYIDFGGVKPMGSEPVPKSRI-NLPAPNPDHVGGY

$\mathrm{Mac}^{-\mathrm{c}} 577$ ALWKGA-ARVFRSSPQFGVTLLTYELLQRWFYIDFGGVKPMGSEPVPKSRI-NLPAPNPDHVGGY

Hor-c 575 ALWKGAGARVFRSSPQFGVTLLTYELLQRWFYIDFGGVKPAGSEPVPKSRI-TLPAPNPDHVGGY

Cat-c 577 ALWKGAGARVFRSPPFGVTLLTYELLQRWFYIDFGGVKPMGSEPVPKSRI-TLPAPNPDHVGGY

Cat-c 577 ALWWGAGRVRSPQFGVTLLTYELLQRWFYIDFGGVKPMGSEPVPKSRI-TLPAPNPDHVGGY
Dog-c 576 ALWKGAGARVRSPQFGVTLLTELLQRWFYIDFGGKPVGSEPVPKSRI-ILPAPNPDHVGGY

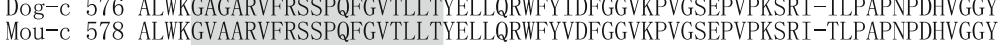

Rat-c 578 ALWKGAGARVFRSSPQFGVTLLTYELLQRWFYVDFGGVKPVGSELVPKSRI-TLPAPNPDHVGGY

Chk-c 576 ALWKGAGARVFRSSPQFGVTLVTYELLQRWFYVDFGGVKPVGSEPVPKSRI-TLPAPNPDHVGGY

X. T-c 298 ALWKGAGARVFRSSPQFGVTLVTYELLQRWFYVDFGGKKPTGAEPVPKSRI-TLPAPNPDHVGGY

Hum-a 575 AFWKGTAARVFRSSPQFGVTLVTYELLQRWFYIDFGGLKPAGSEPTPKSRIADLPPANPDHIGGY

Ora-a 575 AFWKCTARVIRSSPOFCVTLVTYELLORWFIDFCGLKPACSEPTPKSRIADLPPANPDHICGY

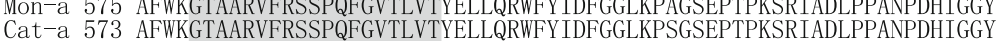

$\begin{array}{ll}\text { Cat-a } & 573 \text { AFWKGTAARVFRSSPFGVTLVTYELLQRWFYIDFGGLKPSGSEPTPKSRIADLPPANPDHIGGY } \\ \text { Dog-a } 575 \text { AFWKGTAARVRSSPQFGVTLVTYELLQRWFYIDFGGLKPSGSEPTPKSRIADLPPANPDHIGGY }\end{array}$

Dog-a 575 AFWKGTAARVFRSSPQFGVTLVTYELLQRWFYIDFGGLKPSGSEPTPKSRIADLPPANPDHIGGY
Mou-a 576 AFWKGTAARVFRSSPQFGVLVTYELLRWFYIDFGGLKPSGSEPTPKSRIADLPPANPDHIGGY

X. T-a 399 ALWKGAGARVFRSSPQFGVTLVTYELLQRWLYVDFGGIKPAGAEPSPKTRISDLPPANPDHIGGY

C. Ele 618 SLWKGTAARVCRSSPQFAVTLLTYEVLQRLFYVDFAGSRPTGSELATTKTIQDESSTNPDHVGGY

TM6 that the [XXVI]-mRNA may be less transcribed or unstable. The SSP and MaxEnt scores in mutation [XXVI] also decreased from 0.99 to $<0.40$ and from 9.73 to 2.09 , respectively.

Novel nonsense and deletion mutations ([XVII]:E16X, [XXVIII]:R306X, [XXIII]:1146delA, [XXX]:1374/5delG)

We found a base substitution from $G$ to $T$ at 46 ([XVII]:E16X) in a Japanese NICCD patient (P758: [IV]/[?]) by direct sequencing of RT-PCR product from exon 1 to exon 18 (-87_2055). Our DNA diagnosis method using PCRRFLP with $P v u I I$ revealed mutation [XVII] in a maternal allele of another family (P919 with mutation [I] in the paternal allele). Genomic DNA analysis of a Japanese NICCD patient (P730 with mutation [II] in maternal allele) revealed a base substitution from $\mathrm{C}$ to $\mathrm{T}$ at 1078 [XXVIII]:R360X in the paternal allele. By RT-PCR/ sequencing, the same [XXVIII] mutation was also found in a Caucasian NICCD patient (P1037) from the Czech Republic.

As shown in Fig. $3 \mathrm{~b}$ and Table 1, we found a 1-bp deletion mutation at 1,146 in exon 11, [XXIII]:1146delA, in a Japanese CTLN2 patient (P549) with [XXII] from maternal allele and confirmed the [XXIII] mutation in her paternal allele by sequencing PCR products from genomic DNA (IVS9-313_IVS11 + 158). The [XXIII] mutation caused a frame shift, leading to a premature termination 
and a truncated form of the citrin protein: R383fs(407X). Furthermore, by using RT-PCR/sequencing, we found a 1bp deletion mutation at 1,374 or 1,375 in exon 14 , [XXX]:1,374/5delG leading to A459fs(507X), in an allele of P1037. We confirmed by analysis with genomic DNA that P1037 was a compound heterozygote with [XXVIII]:R360X and [XXX]:1,374/5delG.

Missense mutations ([XII]:T546M, [XVI]:G531D, [XVIII]:T446P, [XXIX]:R588Q)

A base substitution from $\mathrm{C}$ to $\mathrm{T}$ at 1,637 in exon 16 ([XII]:T546M) was found by RT-PCR/sequencing of the whole coding sequence in the fibroblast RNA of a Japanese CTLN2 patient (P456) with mutation [I] from her maternal allele, who was diagnosed by clinical and biochemical studies (Oshiro et al. 2002). The mutation [XII] was confirmed in her paternal allele by DNA diagnosis. A base substitution from $G$ to $A$ at 1,592 in exon 16 ([XVI]:G531D) was identified by sequencing genomic DNA-PCR from a Japanese CTLN2 patient (P702) with mutation [VIII]:E601X in one allele. By sequencing RT$\mathrm{PCR} /$ genomic DNA-PCR products, a base substitution from $\mathrm{A}$ to $\mathrm{C}$ at 1,336 in exon 14 ([XVIII]:T446P) was found in a maternal allele of an Israeli NICCD patient (P709) with mutation [XXVI]:IVS13 $+2 \mathrm{~T}>\mathrm{G}$ in the paternal allele. On the other hand, we found homozygously a base substitution from $\mathrm{G}$ to $\mathrm{A}$ at 1,763 in exon 17 ([XXIX]:R588Q) in both cDNA and genomic DNA of a Pakistani NICCD patient (P1221) in the UK.

\section{Frequency and distribution of SLC25A13 mutations}

Thirteen novel mutations identified are shown in Table 1 and Fig. 3. These are one insertion, two deletion, three splice-site, two nonsense, and five missense mutations. Of these 13 novel mutations, 12 (all except G531D) were found in both cDNA and genomic DNA, and nine were confirmed in the patients' genomic DNA. These novel mutations were not detected in alleles from more than 50 Japanese control individuals. Western blot analysis showed no mutant citrin in the liver specimens or cultured fibroblast cells of the 11 non-T546M/G531D patients. The residues of the eight (four novel and four known) missense mutations (except P632L) were conserved within the three repeats of mitochondrial transmembrane (TM) spanners located on the $3^{\prime}$ side of citrin, aralar, and homologous proteins from human to Caenorhabditis. elegance (Fig. 4). These results strongly suggest that all mutations except P632L (which is located downstream of the same allele with mutation [I]:851del4) are pathogenic, although further confirmation by functional assay is necessary, especially in the missense mutations.
We also summarized the characteristics of all 30 mutations except [XIII]:P632L found in the SLC25A13 gene involving those described previously (Kobayashi et al. 1999; Yasuda et a. 2000; Yamaguchi et al. 2002; BenShalom et al. 2002; Lu et al. 2005; Takaya et al. 2005; Luder et al. 2006; Hutchin et al. 2006; Sheng et al. 2006; Ko et al. 2007) and assessed their frequency in 334 Japanese, 47 Chinese, 11 Korean, four Vietnamese, and seven non-East Asian families with citrin deficiency (Tables 1, 2). Out of 30 mutations, 12 (two nonsense, five missense, one duplication/insertion, two deletion, and two splice site) were private mutations each found in only one (Japanese, Israeli, Czech Republic, or UK) family. Three missense mutations were detected in more than one family from Japan (E601K and G531D) and in more than one family from Israel (L598R). As mentioned before (Kobayashi et al 2003; Lu et al. 2005), five mutations were found in East Asia: [I]:851del4 in 223 families (173 Japanese, 41 Chinese, five Korean, and four Vietnamese), [II]: IVS11 + 1G > A in 192 families (189 Japanese and three Korean), [III]:1638ins23 in 29 families (20 Japanese and nine Chinese), [V]:IVS13 $+1 \mathrm{G}>\mathrm{A}$ in 50 families (48 Japanese and two Korean), and [X]:IVS6 $+5 \mathrm{G}>\mathrm{A}$ in ten families (one Japanese and nine Chinese). In addition, two novel mutations identified in this study were also found in East Asia: [XVI]:G531D in ten families (seven Japanese and three Chinese), and [XIX]:IVS16ins $3 \mathrm{~kb}$ in 36 families (22 Japanese, six Chinese, and eight Korean).

\section{Discussion}

In this study, we identified for the first time a large pathological insertion mutation [XIX]:IVS16ins $3 \mathrm{~kb}$ into the SLC25A13 gene that was created upon a retrotransposal insertion of cDNA processed from a gene located on chromosome 6 (C6orf68). Babushok and Kazazian (2007) suggest that the integration of LINE-1, SINE elements, and other cellular transcripts by L1 retrotransposition machinery may occasionally cause disease by direct disruption of the target gene. As mutation [XIX]:IVS16ins $3 \mathrm{~kb}$ was found not only in Japanese (3.6\% of mutated alleles) but also in other East Asians such as Chinese, including Taiwanese and Malaysian Chinese (6.4\% of mutated alleles), and Koreans (45.5\% of mutated alleles), this integration using LINE machinery or by infection of retrovirus in a founder may have occurred in a very early historical period in some region of East Asia. We have found that the frequency of mutation [XIX] in Korean patients with citrin deficiency is very high (Table 2) but found no carrier with mutation [XIX] in 2,228 Korean controls.

We have reported that the frequency of homozygotes with SLC25A13 mutations in Japan is calculated to be 
$1: 19,000$ as a minimal estimate from the rate of carriers (1/ 69) (Saheki and Kobayashi 2002; Lu et al. 2005). In this study, we found a heterozygous carrier with mutation [XIX]:IVS16ins3kb in 1,372 Japanese controls, resulting in a carrier rate of 1:65, the same carrier frequency as in China (Lu et al. 2005). Considering the total population of East Asia (about $1.5 \times 10^{9}$ ), more than 100,000 individuals may be homozygotes with SLC25A13 mutations, although further investigation is needed. On the other hand, we have found eight mutations (except [XXVIII]:R360X), which were not found in East Asian patients, in Israel (BenShalom et al. 2002; Luder et al. 2006; this paper), USA (Dimmock et al. 2007), UK (Hutchin et al. 2006; this paper), and the Czech Republic (this paper), indicating that there is genetic heterogeneity among races in citrin deficiency, as described in other diseases such as classical citrullinemia (Gao et al. 2003). It is necessary to perform population analyses with sufficient numbers of controls after identifying novel mutations in each country.

In Japan, the frequency of homozygotes including compound heterozygotes $(1 / 17,000)$ is almost the same as the incidence of NICCD: 1/17,000-34,000 (Shigematsu et al. 2002), but higher than the incidence of CTLN2: 1/100,000-230,000 (Kobayashi et al. 1993). From our observation of Japanese patients, we consider that most homozygotes suffer from NICCD. Following amelioration, some homozygotes may suffer from CTLN2 (10-80 years of age) or be diagnosed as suffering from other diseases, such as pancreatitis (Ikeda et al. 2004), hepatoma (Hagiwara et al. 2003; Tsai et al. 2006; Soeda et al. 2008), hyperlipidemia (Imamura et al. 2003; Terada et al. 2006), fatty liver such as nonalcoholic steatohepatitis (NASH) and nonalcoholic fatty liver disease (NAFLD) (Takagi et al. 2006; Tanaka et al. 2007) or psychosis (Ikeda et al. 2001), but it is probable that many homozygotes remain healthy. To avoid misdiagnosis and mistreatment of patients with citrin deficiency, it is necessary to find them, to treat them properly, and to prevent severer outcomes.

We should realize that the outcome of NICCD patients is not always benign, because four NICCD patients showed severe phenotypes with liver dysfunction and were treated with liver transplantation at the age of 10-12 months (Tamamori et al. 2002). We do not know which NICCD patients, or how many, will go on to develop CTLN2. We need to follow NICCD patients carefully, even during infancy, to investigate their health and to detect the mechanisms and factors that cause severe NICCD and CTLN2. Recently, we described carbohydrate toxicity in patients with CTLN2 (Saheki et al. 2005; Yazaki et al. 2005; Takahashi et al. 2006) and in mouse models of citrin deficiency (Saheki et al. 2007). Intake or administration of large amounts of carbohydrates/sugars, which generate cytosolic $\mathrm{NADH}$, should be avoided. Many CTLN2 patients have a peculiar fondness for protein/lipid-rich foods and aversion for sugar/carbohydrate-rich foods from childhood, probably from weaning, and their symptoms are often provoked by medication, infection, and/or alcohol intake. It is important to find the additional effects of genetic modifiers and/or environmental factors that lead to the deterioration to CTLN2, because we have diagnosed more than 300 cases to be suffering or have suffered from NICCD (220 Japanese, more than 40 Chinese, seven Korean, four Vietnamese, and 12 non-East Asian, including Caucasian) and several Japanese homozygotes and compound heterozygotes without CTLN2 symptoms (three fathers or two mothers of NICCD and 13 siblings of CTLN2 patients).

Acknowledgments We are grateful to the patients and their families as well as to the following physicians who provided samples and clinical information relating to the analysis of SLC25A13 mutations: Y. Takei, M. Yazaki and S. Ikeda (Shinshu University), T. Tana (Ryukyu University), E. Hashimoto (Tokyo Women's Medical University), N. Onoda (Shuwa General Hospital), T. Kobayashi (Jichi Medical University), K. Hosoki (Mie General Medical Center), Y. Hasegawa (Kiyose Children's Hospital), O. Elpeleg (Shaare Zedek Medical Center), E. Pospisilova (Charles University), and T. Hutchin (Birmingham Children's Hospital). We also thank T. Yasuda, N. Yamaguchi, L. Begum, M.A. Jalil, and M. Horiuchi for technical assistance, and M. Gore for editorial assistance (Kagoshima University). This study was supported in part by Grants-in-Aid for Scientific Research (B: Nos. 16390100 and 19390096) and for Asia-Africa Scientific Platform Program from the Japan Society for the Promotion of Science, and by a Grant for Child Health and Development (17-2) from the Ministry of Health, Labour and Welfare in Japan.

\section{References}

Babushok DV, Kazazian HH Jr (2007) Progress in understanding the biology of the human mutagen LINE-1. Hum Mutat 28:527-539

Ben-Shalom E, Kobayashi K, Shaag A, Yasuda T, Gao H-Z, Saheki T, Bachmann C, Elpeleg O (2002) Infantile citrullinemia caused by citrin deficiency with increased dibasic amino acids. Mol Genet Metab 77:202-208

Dimmock D, Kobayashi K, Iijima M, Tabata A, Wong LJ, Saheki T, Lee B, Scaglia F (2007) Citrin deficiency: a novel cause of failure to thrive that responds to a high protein, low carbohydrate diet. Pediatrics, 119:773-777

Gao H-Z, Kobayashi K, Tabata A, Tsuge H, Iijima M, Yasuda T, Kalkanoglu HS, Dursun A, Tokatli A, Coskun T, Trefz FK, Skladal D, Mandel H, Seidel J, Kodama S, Shirane S, Ichida T, Makino S, Yoshino M, Kang J-H, Mizuguchi M, Barshop BA, Fuchinoue S, Seneca S, Zeesman S, Knerr I, Rodés M, Wasant P, Yoshida I, De Meirleir L, Jalil MA, Begum L, Horiuchi M, Katunuma N, Nakagawa S, Saheki T (2003) Identification of 16 novel mutations in the argininosuccinate synthetase gene and genotype-phenotype correlation in 38 classical citrullinemia patients. Hum Mutat 22:24-34

Hagiwara N, Sekijima Y, Takei Y, Ikeda S, Kawasaki S, Kobayashi K, Saheki T (2003) Hepatocellular carcinoma in a case of adultonset type II citrullinemia. Intern Med 42:978-982

Hutchin T, Preece MA, Kobayashi K, Saheki T, Brown R, Kelly DA, McKiernan PJ, Green A, Baumann U (2006) Neonatal intrahepatic cholestasis caused by citrin deficiency (NICCD) in a European patient. J Inherit Metab Dis 29(Suppl 1):112 
Hwu W-L, Kobayashi K, Hu Y-H, Yamaguchi N, Saheki T, Chou SP, Wang J-H (2001) A Chinese adult onset type II citrullinaemia patient with 851del4/1638ins23 mutations in the SLC25A13 gene. J Med Genet 38:E23

Ikeda S, Yazaki M, Takei Y, Ikegami T, Hashikura Y, Kawasaki S, Iwai M, Kobayashi K, Saheki T (2001) Type II (adult onset) citrullinaemia: clinical pictures and the therapeutic effect of liver transplantation. J Neurol Neurosurg Psychiatry 71:663-670

Ikeda S, Kawa S, Takei Y, Yamamoto K, Shimojo H, Tabata K, Kobayashi K, Saheki T (2004) Chronic pancreatitis associated with adult-onset type II citrullinemia: clinical and pathologic findings. Ann Intern Med 141:W109-W110

Imamura Y, Kobayashi K, Shibatou T, Aburada S, Tahara K, Kubozono O, Saheki T (2003) Effectiveness of carbohydraterestricted diet and arginine granules therapy for adult-onset type II citrullinemia: a case report of siblings showing homozygous SLC25A13 mutation with and without the disease. Hepatol Res 26:68-72

Kasahara M, Ohwada S, Takeichi T, Kaneko H, Tomomasa T, Morikawa A, Yonemura K, Asonuma K, Tanaka K, Kobayashi K, Saheki T, Takeyoshi I, Morishita Y (2001) Living-related liver transplantation for type II citrullinemia using a graft from heterozygote donor. Transplantation 71:157-159

Kim SZ, Jeon YM, Song WJ, Ushikai M, Saheki T, Kobayashi K (2006) Two cases of citrin deficiency detected by newborn screening in Korea. J Inherit Metab Dis 29(Suppl 1):84

Ko JM, Kim GH, Kim JH, Kim JY, Choi JH, Ushikai M, Saheki T, Kobayashi K, Yoo HW (2007) Six cases of citrin deficiency in Korea. Int J Mol Med 20:809-815

Kobayashi K, Shaheen N, Kumashiro R, Tanikawa K, O'Brien WE, Beaudet AL, Saheki T (1993) A search for the primary abnormality in adult-onset type II citrullinemia. Am J Hum Genet 53:1024-1030

Kobayashi K, Horiuchi M, Saheki T (1997) Pancreatic secretory trypsin inhibitor as a diagnostic marker for adult-onset type II citrullinemia. Hepatology 25:1160-1165

Kobayashi K, Sinasac DS, Iijima M, Boright AP, Begum L, Lee JR, Yasuda T, Ikeda S, Hirano R, Terazono H, Crackower MA, Kondo I, Tsui L-C, Scherer SW, Saheki T (1999) The gene mutated in adult-onset type II citrullinemia encodes a putative mitochondrial carrier protein. Nat Genet 22:159-163

Kobayashi K, Lu YB, Li MX, Nishi I, Hsiao KJ, Choeh K, Yang Y, Hwu WL, Reichardt JK, Palmieri F, Okano Y, Saheki T (2003) Screening of nine SLC25A13 mutations: their frequency in patients with citrin deficiency and high carrier rates in Asian populations. Mol Genet Metab 80:356-359

Lee N-C, Chien Y-H, Kobayashi K, Saheki T, Chen H-L, Chiu P-C, Ni Y-H, Chang M-H, Hwu W-L (2006) Time course of acylcarnitine elevation in neonatal intrahepatic cholestasis caused by citrin deficiency. J Inherit Metab Dis 29:551-555

Liu L, Kobayashi K, Ushikai M, Saheki T, Li XZ, Mei HF, Cheng J (2006) SLC25A13 mutation analysis in Chinese hepatitis syndrome infants. J Inherit Metab Dis 29(Suppl 1):26

Lu YB, Kobayashi K, Ushikai M, Tabata A, Iijima M, Li MX, Lei L, Kawabe K, Taura S, Yang Y, Liu T-T, Chiang S-H, Hsiao K-J, Lau Y-L, Tsui L-C, Lee DH, Saheki T (2005) Frequency and distribution in East Asia of 12 mutations identified in the SLC25A13 gene of Japanese patients with citrin deficiency. J Hum Genet 50:338-346

Luder AS, Tabata A, Iijima M, Kobayashi K, Mandel H (2006) Citrullinaemia type 2 outside East Asia: Israeli experience. J Inherit Metab Dis 29(Suppl 1):59

Ohura T, Kobayashi K, Tazawa Y, Nishi I, Abukawa D, Sakamoto O, Iinuma K, Saheki T (2001) Neonatal presentation of adult-onset type II citrullinemia. Hum Genet 108:87-90
Ohura T, Kobayashi K, Tazawa Y, Abukawa D, Sakamoto O, Tsuchiya S, Saheki T (2007) Clinical pictures of 75 patients with neonatal intrahepatic cholestasis caused by citrin deficiency. J Inherit Metab Dis 30:139-144

Oshiro S, Kochinda T, Tana T, Yamazato M, Kobayashi K, Komine Y, Muratani H, Saheki T, Iseki K, Takishita S (2002) A patient with adult-onset type II citrullinemia on long-term hemodialysis: reversal of clinical symptoms and brain MRI findings. Am J Kidney Dis 39:189-192

Palmieri L, Pardo B, Lasorsa FM, del Arco A, Kobayashi K, Iijima M, Runswick MJ, Walker JE, Saheki T, Satrústegui J, Palmieri F (2001) Citrin and aralar1 are $\mathrm{Ca}^{2+}$-stimulated aspartate/glutamate transporters in mitochondria. EMBO J 20:5060-5069

Saheki T, Kobayashi K (2002) Mitochondrial aspartate glutamate carrier (citrin) deficiency as the cause of adult-onset type II citrullinemia (CTLN2) and idiopathic neonatal hepatitis (NICCD). J Hum Genet 47:333-341

Saheki T, Kobayashi K, Miura T, Hashimoto S, Ueno Y, Yamasaki T, Araki H, Nara H, Shiozaki Y, Sameshima Y, Suzuki M, Yamauchi Y, Sakazume Y, Akiyama K, Yamamura Y (1986) Serum amino acid pattern of type II citrullinemic patients and effect of oral administration of citrulline. J Clin Biochem Nutr $1: 129-142$

Saheki T, Kobayashi K, Inoue I (1987) Hereditary disorders of the urea cycle in man: biochemical and molecular approaches. Rev Physiol Biochem Pharmacol 108:21-68

Saheki T, Kobayashi K, Iijima M, Moriyama M, Yazaki M, Takei Y, Ikeda S (2005) Metabolic derangements in deficiency of citrin, a liver-type mitochondrial aspartate-glutamate carrier. Hepatol Res 33:181-184

Saheki T, Iijima M, Li MX, Kobayashi K, Horiuchi M, Ushikai M, Okumura F, Meng XJ, Inoue I, Tajima A, Moriyama M, Eto K, Kadowaki T, Sinasac DS, Tsui L-C, Tsuji M, Okano A, Kobayashi T (2007) Citrin/mitochondrial glycerol 3-phosphate dehydrogenase double knock-out mice recapitulate features of human citrin deficiency. J Biol Chem 282:25041-2505

Sheng J-S, Ushikai M, Iijima M, Packman S, Weisiger K, Martin M, McCracken M, Saheki T, Kobayashi K (2006) Identification of a novel mutation in a Taiwanese patient with citrin deficiency. $\mathrm{J}$ Inherit Metab Dis 29(Suppl 1):163

Shigematsu Y, Hirano S, Hata I, Tanaka Y, Sudo M, Sakura N, Tajima T, Yamaguchi S (2002) Newborn mass screening and selective screening using electrospray tandem mass sprctrometry in Japan. J Chromatogr B 776:39-48

Soeda J, Yazaki M, Nakata T, Miwa S, Ikeda S, Hosoda W, Iijima M, Kobayashi K, Saheki T, Kojiro M, Miyagawa S (2008) Primary liver carcinoma exhibiting dual hepatocellular-biliary epithelial differentiations associated with citrin deficiency: a case report and review of the literature. J Clin Gastroenterol (in press)

Song Y-Z, Hao H, Ushikai M, Liu G-S, Xiao X, Saheki T, Kobayashi K, Wang Z-N (2006) A difficult and complicated case study: neonatal intrahepatic cholestasis caused by citrin deficiency (in Chinese). Chin J Contemp Pediatr 8:125-128

Song Y-Z, Ushikai M, Sheng J-S, Iijima M, Kobayashi K (2007) SLC25A13 gene mutation analysis in a pedigree of neonatal intrahepatic cholestasis caused by citrin deficiency (in Chinese). Chin J Pediatr 45:408-412

Takahashi H, Kagawa T, Kobayashi K, Hirabayashi H, Yui M, Begum L, Mine T, Takagi S, Saheki T, Shinohara Y (2006) A case of adult-onset type II citrullinemia: deterioration of clinical course after infusion of hyperosmotic and high sugar solutions. Med Sci Monit 12:CS13-CS15

Takagi H, Hagiwara S, Hashizume H, Kanda D, Sato K, Sohara N, Kakizaki S, Takahashi H, Mori M, Kaneko H, Ohwada S, Ushikai M, Kobayashi K, Saheki T (2006) Adult onset type II 
citrullinemia as a cause of non-alcoholic steatohepatitis. J Hepatol 44:236-239

Takaya J, Kobayashi K, Ohashi A, Ushikai M, Tabata A, Fujimoto S, Yamato F, Saheki T, Kobayashi Y (2005) Variant clinical courses of 2 patients with neonatal intrahepatic cholestasis who have a novel mutation of SLC25A13. Metabolism 54:1615-1619

Tamamori A, Okano Y, Ozaki H, Fujimoto A, Kajiwara M, Fukuda K, Kobayashi K, Saheki T, Tagami Y, Yamano T (2002) Neonatal intrahepatic cholestasis caused by citrin deficiency: severe hepatic dysfunction in an infant requiring liver transplantation. Eur J Pediatr 161:609-613

Tanaka N, Yazaki M, Kobayashi K (2007) A lean man with nonalcoholic fatty liver disease. Clin Gastroenterol Hepatol 5:32

Tazawa Y, Kobayashi K, Ohura T, Abukawa D, Nishinomiya F, Hosoda Y, Yamashita M, Nagata I, Kono Y, Yasuda T, Yamaguchi N, Saheki T (2001) Infantile cholestatic jaundice associated with adult-onset type II citrullinemia. J Pediatr 138:735-740

Tazawa Y, Kobayashi K, Abukawa D, Nagata I, Maisawa S, Sumazaki R, Iizuka T, Hosoda Y, Okamoto M, Murakami J, Kaji S, Tabata A, Lu YB, Sakamoto O, Matsui A, Kanzaki S, Takada G, Saheki T, Iinuma K, Ohura T (2004) Clinical heterogeneity of neonatal intrahepatic cholestasis caused by citrin deficiency: case reports from 16 patients. Mol Genet Metab 83:213-219

Terada R, Yamamoto K, Kobayashi K, Sakaguchi K, Iwasaki Y, Saheki T, Shiratori Y (2006) Adult-onset type II citrullinemia associated with idiopathic hypertriglyceridemia as a preceding feature. J Gastroenterol Hepatol 21:1634-1635

Tokuhara D, Iijima M, Tamamori A, Ohura T, Takaya J, Maisawa S, Kobayashi K, Saheki T, Yamano T, Okano Y (2007) Novel diagnostic approach to citrin deficiency: analysis of citrin protein in lymphocytes. Mol Genet Metab 90:30-36

Tomomasa T, Kobayashi K, Kaneko H, Shimura H, Fukusato T, Tabata M, Inoue Y, Ohwada S, Kasahara M, Morishita Y,
Kimura M, Saheki T, Morikawa A (2001) Possible clinical and histologic manifestations of adult-onset type II citrullinemia in early infancy. J Pediatr 138:741-743

Tsai C-W, Yang C-C, Chen H-L, Hwu W-L, Wu M-Z, Liu K-L, Wu M-S (2006) Homozygous SLC25A13 mutation in a Taiwanese patient with adult-onset citrullinemia complicated with steatosis and hepatocellular carcinoma. J Formos Med Assoc 105:852856

Waki M, Mutoh K, Murata K, Uemoto S, Kobayashi K (2004) Severe hyperlipidemia in a patient with adult-onset type II citrullinemia, associated with decreased lipoprotein lipase protein and dysgenesis of the corpus callosum (in Japanese). Lipid 15:266-270

Yamaguchi N, Kobayashi K, Yasuda T, Nishi I, Iijima M, Nakagawa M, Osame M, Kondo I, Saheki T (2002) Screening of SLC25A13 mutations in early and late onset patients with citrin deficiency and in the Japanese population: identification of two novel mutations and establishment of multiple DNA diagnosis methods for nine mutations. Hum Mutat 19:122-130

Yang YL, Tagami Y, Saheki T, Kobayashi K, Li MX, Hanai J, Fujita K, Yuan Y, Qin J (2003) Genetic analysis of a family with adultonset type II citrullinemia (in Chinese). Chin J Med Genet 20:380

Yasuda T, Yamaguchi N, Kobayashi K, Nishi I, Horinouchi H, Jalil MA, Li MX, Ushikai M, Iijima M, Kondo I, Saheki T (2000) Identification of two novel mutations in the SLC25A13 gene and detection of seven mutations in 102 patients with adult-onset type II citrullinemia. Hum Genet 107:537-545

Yazaki M, Takei Y, Kobayashi K, Saheki T, Ikeda S (2005) Risk of worsened encephalopathy after intravenous glycerol therapy in patients with adult-onset type II citrullinemia (CTLN2). Intern Med 44:188-195

Yeh J-N, Jeng Y-M, Chen H-L, Ni Y-H, Hwu W-L, Chang M-H (2006) Hepatic steatosis and neonatal intrahepatic cholestasis caused by citrin deficiency (NICCD) in Taiwanese infants. J Pediatr 148:642-646 